\title{
Acquired platelet dysfunction with eosinophilia: review of seven adult cases
}

\author{
S H LIM,* C E TAN, T AGASTHIAN, L S CHEW \\ From the *Department of Haematology, Singapore General Hospital, and the Department of Medicine, \\ Alexandra Hospital, Singapore
}

SUMMARY Seven adults with acquired platelet dysfunction with eosinophilia presented with histories of spontaneous bruising and three also had moderate thrombocytopenia. Six patients had platelet function tests performed and all showed variable storage pool defects. When assayed, IgE concentrations were raised. Although only two patients had parasites isolated in their stools, all seven responded to antihelminth treatment. It is speculated that the IgE response to parasites mediates mast cell degranulation, which leads to in vivo platelet activation.

The acquired platelet dysfunction with eosinophilia syndrome has, to date, been described only in South East Asia. It was previously thought to be unique to children, ${ }^{1-3}$ but a few adult cases have since been reported. ${ }^{4-5}$ Platelet function tests in these patients have shown variable storage pool defects. ${ }^{4}$ We describe our experience of seven examples in young healthy men and speculate on the pathophysiology of this peculiar syndrome.

\section{Patients and methods}

Seven previously healthy Chinese men aged 19 to 22 years had been seen in our unit over the past year for extensive, spontaneous bruising over both upper and lower limbs. None had any personal or family history of bleeding tendencies or atopy; and none had taken any drugs recently. Only one patient had an antecedent illness - a three month history of recurrent epigastric pain and diarrhoea. Stool and blood examinations were negative in this patient and gastroscopy was normal, so he was thought to have the irritable bowel syndrome.

Physical examination in all yielded normal results except for the ecchymoses. Bruising was confined to the limbs, especially around the elbows and knees. Each ecchymosis measured 2 to $7 \mathrm{~cm}$ in diameter with a tender raised central nodule 1 to $2 \mathrm{~cm}$ in diameter. All seven patients were given mebendazole $100 \mathrm{mg}$ twice a day for three days, irrespective of whether the stools were positive for helminths. Three patients had repeated courses of mebendazole because of recurrent eosinophilia during follow up. Five patients were followed up for at least six months.

Accepted for publication 12 April 1989
Stool cultures were repeated at least three times during hospital stay for all patients and again during follow up when eosinophilia recurred. The IgE titre was assayed using a Phadebas IgE Prist kit and the platelet aggregation studies performed on the Cronolog aggregonometer using platelet rich plasma with platelet concentrations of $200-400 \times 10^{9} / 1$ Platelet function tests were not repeated in any of these patients as previous studies have shown the defects to be transient. ${ }^{45}$

\section{Results}

The results are summarised in tables 1-3. All patients had eosinophilia, ranging from 1.8-7.0 $\times 10^{9} / 1$. In contrast to previous reports ${ }^{145}$ the platelet counts in cases 1,3 , and 5 were below $100 \times 10^{9} / 1$. Platelet dysfunctions were variable. Stools in cases 4 and 6 contained isolates of Stronglyloides stercoralis.

Low serum CH50 concentrations were found in all four patients; IgE concentrations, assayed only on the first five patients, were all raised. Biopsy specimens of

Table 1 Platelet counts and stool findings

\begin{tabular}{llll}
\hline Case No & $\begin{array}{l}\text { White cell count } \\
\times 10^{9} / l\end{array}$ & $\begin{array}{l}\text { Eosinophils } \\
\times 10^{9} / l\end{array}$ & $\begin{array}{l}\text { Stool } \\
\text { findings }\end{array}$ \\
\hline 1 & 13.6 & 4.6 & Negative \\
2 & 15.5 & 7.0 & Negative \\
3 & 9.4 & 2.4 & Negative \\
4 & 19.0 & 3.9 & S stercoralis \\
5 & 8.7 & 1.9 & Negative \\
6 & 12.4 & 4.0 & S stercoralis \\
7 & 8.2 & 1.8 & Negative \\
\hline
\end{tabular}


Table 2 Immunoglobulin and CH5O concentration

\begin{tabular}{|c|c|c|c|c|c|c|}
\hline Case No & $I g G$ & $I g M$ & $\operatorname{Ig} A$ & $\operatorname{Ig} E(I U / l)$ & $\operatorname{IgE}(I U / I)^{*}$ & CH5O (IU/l) \\
\hline $\begin{array}{l}1 \\
2 \\
3 \\
4 \\
5 \\
6 \\
7\end{array}$ & $\begin{array}{l}\text { Normal } \\
\text { Normal } \\
\text { Normal } \\
\text { Raised } \\
\text { Normal } \\
\text { Normal } \\
\text { Not done }\end{array}$ & $\begin{array}{l}\text { Normal } \\
\text { Normal } \\
\text { Normal } \\
\text { Normal } \\
\text { Normal } \\
\text { Normal } \\
\text { Not done }\end{array}$ & $\begin{array}{l}\text { Normal } \\
\text { Normal } \\
\text { Normal } \\
\text { Normal } \\
\text { Normal } \\
\text { Normal } \\
\text { Not done }\end{array}$ & $\begin{array}{c}416 \\
195 \\
>2000 \\
>2000 \\
654 \\
\text { Not done } \\
\text { Not done }\end{array}$ & $\begin{array}{l}\text { Not done } \\
\text { Not done } \\
\text { Not done } \\
\text { Not done } \\
318 \\
\text { Not done } \\
\text { Not done }\end{array}$ & $\begin{array}{l}32 \\
34 \\
30 \\
39 \\
\text { Not done } \\
\text { Not done } \\
\text { Not done }\end{array}$ \\
\hline
\end{tabular}

$I g E^{*}=$ IgE concentrations six weeks after starting antihelminth treatment.

the nodules in cases 2 and 3 showed only blood clot and fibrin with no cellular or eosinophilic infiltrate.

Response to antihelminth treatment was interesting. In cases 4 and 6 with Strongyloides infestations, all skin lesions healed within two weeks of completing the treatment. Repeat stool cultures were negative for Strongyloides. Case 4 had a dramatic eosinophil response but case 6 showed only a marginal drop in eosinophil count. This patient defaulted from follow up and we were therefore unable to determine if there was a delayed eosinophil response.

Four of the other patients showed an equally dramatic response within two weeks of completing treatment. Skin lesions resolved and the eosinophil counts returned to normal. Case 3 had a delayed response to antihelminth treatment. The eosinophil count persisted between $2.0-3.9 \times 10^{9} / 1$ but his ecchymoses resolved. He had a recurrence three months later and was given three courses of mebendazole, after which he had no further recurrence and his last eosinophil count was $0.24 \times 10^{9} / 1$.

The gastrointestinal and skin symptoms in case 2 resolved completely after antihelminth treatment. We suggest that this further points towards a common pathology.

\section{Discussion}

The acquired platelet dysfunction with eosinophilia syndrome has been described only in South East Asia. It is the commonest cause of spontaneous bruising among Thai children. ${ }^{1}$ It has been described among both children and adolescents. ${ }^{3-5}$ It runs a self limiting course and spontaneous recovery occurs within six months to a year after onset of symptoms.

All seven patients in our series presented with typical bruising, confined mainly to the upper and lower limbs. The reasons for this pattern of distribution are unclear.

Previous studies had shown patients to have only qualitative platelet defects; none had platelet counts of less than $100 \times 10^{9} / 1^{1-5}$ In three of our patients, however, moderate thrombocytopenia occurred, suggesting that this could be the other end of the spectrum of the condition.

With low serum $\mathrm{CH} 50$ and raised IgE concentrations, our series suggested that a type 1 IgE mediated reaction to either a parasite or other allergen was responsible. Judging by previous studies of IgE concentrations and response, ${ }^{67}$ these raised IgE concentrations were probably due to live parasites, some of which may have been too small or the wormload too low to be detected on routine stool examination. This is supported by the observation that almost all our patients responded to antihelminth treatment.

The association between the IgE mediated reaction and the variable platelet dysfunction remains speculative. Our results and those of previous studies ${ }^{45}$ all point towards an acquired storage pool defect. This defect is probably due to an in vivo platelet activation, a situation similar to those reported in myeloproliferative disease. ${ }^{8}$ Here, the activation is most likely to be mediated by platelet activating factor (PAF) released from IgE mediated mast cell degranulation.' Hence platelet release and aggregation occur in vivo and lead to an acquired storage pool defect and

Table 3 Platelet counts and platelet aggregation tests

\begin{tabular}{|c|c|c|c|c|c|c|c|}
\hline $\begin{array}{l}\text { Case } \\
\text { No }\end{array}$ & $\begin{array}{l}\text { Platelet } \\
\text { count } \times\end{array}$ & $10^{9} / / \mathrm{PF} 3$ & $\begin{array}{l}\text { Collagen } \\
(3 \mu \mathrm{g} / \mathrm{ml})\end{array}$ & $\begin{array}{l}A D P \\
(5 \mu \mathrm{g} / \mathrm{ml})\end{array}$ & $\begin{array}{l}\text { Adrenaline } \\
(62 \mu \mathrm{g} / \mathrm{ml})\end{array}$ & $\begin{array}{l}\text { Arachidonic } \\
\text { acid }(2 \mathrm{mmol} / \mathrm{l})\end{array}$ & $\begin{array}{l}\text { Ristocetin } \\
(1.5 \mathrm{mg} / \mathrm{ml})\end{array}$ \\
\hline $\begin{array}{l}1 \\
2 \\
3 \\
4 \\
5 \\
6 \\
7\end{array}$ & $\begin{array}{r}85 \\
150 \\
70 \\
150 \\
35 \\
140 \\
145\end{array}$ & $\begin{array}{l}\text { Normal } \\
\text { Normal } \\
\text { Normal } \\
\text { Not done } \\
\text { Normal } \\
\text { Normal } \\
\text { Abnormal }\end{array}$ & $\begin{array}{l}\text { Abnormal } \\
\text { Abnormal } \\
\text { Abnormal } \\
\text { Not done } \\
\text { Abnormal } \\
\text { Normal } \\
\text { Abnormal }\end{array}$ & $\begin{array}{l}\text { Abnormal } \\
\text { Normal } \\
\text { Normal } \\
\text { Not done } \\
\text { Abnormal } \\
\text { Normal } \\
\text { Normal }\end{array}$ & $\begin{array}{l}\text { Abnormal } \\
\text { Normal } \\
\text { Normal } \\
\text { Not done } \\
\text { Abnormal } \\
\text { Abnormal } \\
\text { Abnormal }\end{array}$ & $\begin{array}{l}\text { Normal } \\
\text { Abnormal } \\
\text { Abnormal } \\
\text { Not done } \\
\text { Abnormal } \\
\text { Abnormal } \\
\text { Abnormal }\end{array}$ & $\begin{array}{l}\text { Normal } \\
\text { Normal } \\
\text { Normal } \\
\text { Not done } \\
\text { Normal } \\
\text { Normal } \\
\text { Normal }\end{array}$ \\
\hline
\end{tabular}


variable thrombocytopenia. This also explains the observation that platelet aggregation response lags behind eosinophil response. ${ }^{4}$ To prove this, in vivo platelet activation and consumption, bone marrow aspirate, and measurements of serum platelet factor 4 , platelet derived growth factors, and $\beta$ thromboglobulin for evidence of platelet release and consumption are necessary.

There is probably a genetic component to this syndrome. Similar hypersensitive reaction in skin conditions like eosinophilic cellulitis ${ }^{10}$ and eosinophilic panniculitis ${ }^{11}$ seen among the caucasian population are not seen in South East Asia. Whether all these three skin conditions are a spectrum of manifestation of a type $1 \mathrm{IgE}$ mediated reaction modified by the genetic background of the individual needs to be determined by further studies.

\section{References}

1 Mitrakul C. Transient spontaneous bruising with long bleeding time and normal platelet count. Am J Clin Pathol 1975;63:81-6.

2 Suvatte V, Mahasandana C, Tanphaichitr V. Acquired platelet dysfunction with eosinophilia: study of platelet function in 62 cases. South East Asia Journal of Tropical Medicine and Public Health 1979;10:358-67.

3 Ramanathan M, Duraisamy G. Acquired platelet dysfunction with eosinophilia (APDE): an under recognised condition. Med J Malaysia 1987;42:53-5.

4 Kueh YK, Chan L, Lim BC, Wong HB. Transient non-thrombocytopenic purpura in hookworm infestation. Scand J Haematol 1983;30:174-6.

5 Teo CG, Ting WC. Thrombocytopathic purpura associated with eosinophilia. Trans Roy Soc Trop Med Hyg 1984;78:335-8.

6 Jarrett EE, Miller HRP. Production and activities of IgE in helminth infection. Prog Allergy 1982;31:178-233.

7 Cohen S, Warren KS. Immunology of parasitic infections. 2nd edition. Oxford: Blackwell Scientific Publication, 1982.

8 Boughton BJ, Corbett WEN, Ginsberg AD. Myeloproliferative disorders: a paradox of in vivo and in vitro platelet function. J Clin Pathol 1977;30:228-34.

9 Mitchell BE. The mast cell: structure and function. Hosp Update 1983;9:1367-77.

10 Wells GC, Smith NP. Eosinophilic cellulitis. Br J Dermatol 1979; 100:101-9.

11 Winkelmann RK, Frigas E. Eosinophilic panniculitis: a clinicopathologic study. J Cutan Pathol 1986;13:1-12.

Requests for reprints to: Dr S H Lim, Department of Haematology, Singapore General Hospital, Outram Road, Singapore. 